\title{
Securing Human Rights Intellectually: Philosophical Inquiries about the Universal Declaration
}

\section{Citation}

Risse, Mathias. 2009. Securing Human Rights Intellectually: Philosophical Inquiries about the Universal Declaration. HKS Faculty Research Working Paper Series RWP09-024, John F. Kennedy School of Government, Harvard University.

\section{Published Version}

http://web.hks.harvard.edu/publications/workingpapers/citation.aspx?Publd=6748

\section{Permanent link}

http://nrs.harvard.edu/urn-3:HUL.InstRepos:4449103

\section{Terms of Use}

This article was downloaded from Harvard University's DASH repository, and is made available under the terms and conditions applicable to Other Posted Material, as set forth at http:// nrs.harvard.edu/urn-3:HUL.InstRepos:dash.current.terms-of-use\#LAA

\section{Share Your Story}

The Harvard community has made this article openly available.

Please share how this access benefits you. Submit a story.

\section{Accessibility}




\title{
MARVARD Kennedy School JOHN F. KENNEDY SCHOOL OF GOVERNMENT
}

\author{
Faculty Research Working Papers Series
}

Securing Human Rights Intellectually: Philosophical Inquiries about the Universal Declaration

\author{
Mathias Risse \\ John F. Kennedy School of Government - Harvard University
}

August 2009

RWP09-024

The views expressed in the HKS Faculty Research Working Paper Series are those of the author(s) and do not necessarily reflect those of the John F. Kennedy School of Government or of Harvard University. Faculty Research Working Papers have not undergone formal review and approval. Such papers are included in this series to elicit feedback and to encourage debate on important public policy challenges. Copyright belongs to the author(s). Papers may be downloaded for personal use only. 


\title{
Securing Human Rights Intellectually: Philosophical Inquiries about the Universal Declaration
}

\author{
Mathias Risse \\ John F. Kennedy School of Government, Harvard University
}

August 4, 2009

1. The Universal Declaration of Human Rights (UDHR) was passed by the General Assembly of the United Nations on December 10, 1948. ${ }^{1}$ The evening before, Charles Malik, a Lebanese philosopher and diplomat, one of its drafters, introduced the document. In his speech, he

pointed each country to places in the Declaration where it could either find its own contributions or the influence of the culture to which it belonged. The Latin American countries had brought to the process the ideas and experiences gained in preparing the Bogotá Declaration on the Rights and Duties of Man. India had played a key role in advancing the nondiscrimination principle, especially with regard to women. France was responsible for many elegancies in drafting. The United Kingdom and the United States had shared the wisdom acquired in their long experience with traditional political and civil liberties. The Soviet Union, with broad support from many quarters, had championed the newer social and economic rights in the interest of 'improving the living conditions of the broad masses of mankind.' The importance of remembering that rights entail duties had been emphasized by participants from China, Greece, Latin America, the Soviet Union, and France. Many countries had contributed to the article of freedom of religion and rights of the family. Due to the immense variety of its sources, the Declaration had been constructed on a 'firm international basis where no regional philosophy or way of life was permitted to prevail.’ (Glendon (2001), pp 164f)

Malik's insistence that "no regional philosophy or way of life was permitted to prevail" received a striking confirmation in Eleanor Roosevelt's speech that stressed that, had the United States gotten its way, certain aspects of the UDHR would look different.

The language of human rights has become the most common language of emancipation. When organized power is criticized for harming those whom it ought to

\footnotetext{
${ }^{1}$ This article is intended for an edited volume by Stephen Kosslyn and Evelynn Hammonds in the series The New Harvard Bookshelf: Towards a Liberal Education for the $21^{\text {st }}$ Century. The purpose of that collection is to bring together articles that capture the basic ideas of different courses offered in the general education curriculum of Harvard College. This article is based on the syllabus of my course Human Rights: A Philosophical Introduction (ER11).
} 
benefit, appeals to human rights tend to be used, rather than the language of Marxism, critical theory, modernization theory, dependency theory, or other decidedly moral languages, like the language of justice or plainly of rights and duties as opposed to "human” rights. Politicians and political activists (even academics in their research) are trying to frame their goals in the language of human rights, aligning themselves with the UDHR or other major human rights documents. Especially since the end of the Cold War, the human rights movement - earlier often confined to candle light vigils -- has established a major presence in international politics. Organizations like Amnesty International, Human Rights Watch, Doctors Without Borders, Human Rights First, and many more have become very visible.

Social scientists have recently started to explore whether the use of the human rights language correlates to improvements in people's lives. International relations specialists seek to evaluate whether, for instance, a country's signing human rights conventions is linked to improvements in the conditions of the population (fewer civil rights violations, improved abilities to make a living, etc.) So far the results are mixed. Qualitative, case-study-based, inquiries have identified mechanisms through which human rights documents and organizations could readily make a difference in domestic politics. A country ruled by an oppressive regime might ratify treaties to improve its reputation abroad and perhaps obtain better access to foreign aid. Domestic opposition might challenge the government to abide by rules they have ostensibly accepted. International organizations may contribute to this process of "naming and shaming," or provide logistic support or training. Eventually the government can no longer ignore these pressures, and first has to engage the human rights activists politically (a victory for the latter), and eventually make changes for the better.

Social scientists have found success stories of this sort for instance in countries in Eastern Europe and Central America. Alas, more quantitatively oriented researchers looking at cross-country data-sets - failed to confirm this optimism. Statistical analyses of the effects of compliance with human rights treaties have so far spread pessimism about compliance with human rights treatises rather than confirm optimism. (For case studies that inspire optimism, see Risse et al. (1999). For the statistical pessimism, see e.g. Hathaway (2002).) This is a peculiar state-of-the-art, but this area is still emerging, 
and much more work needs to be done. In any event, one should not confuse the ubiquity of the human rights language with actual impact. Inquiries into the effects of human rights language are only one example of the newly-burgeoning field of "human rights studies." Other developments include historians looking into the intellectual and political changes that led to the human rights movement, and specifically diplomatic historians investigating the history of certain states taking particular stances on human rights issues, as well as anthropologists exploring the impact of the human rights movement on indigenous ways of articulating complaints about mistreatment.

But it is not a social-scientific evaluation of the human rights movement that is the topic of Ethical Reasoning 11: A Philosophical Introduction to Human Rights. My concerns are with the philosophical foundations of human rights. The idea behind "human" rights is that individuals have rights simply in virtue of being human whose realization is not merely of concern to the states in which they happen to live, but a global responsibility. To assess the intellectual credibility of human rights we must ask: Why would human beings have such rights, and what such rights are there? These are the guiding questions of this course, and they take us into foundational questions about morality that at the same time are becoming increasingly more important in a politically, economically, and culturally interconnected world. Related topics that this course also explores include the relativism/universalism debate and the question of what to make specifically of social and economic rights, rights whose standing as human rights has often been criticized, on both philosophical and political grounds. A suspicion about human rights one must beat to establish their intellectual (and thus ultimately their political) credibility is that they are $19^{\text {th }}$ century standards of civilization in disguise standards that determine the conditions under which people elsewhere get to enjoy the benefits of interaction with Europeans and their descendants.

It is in virtue of asking such questions that ER11 is part of the ethical-reasoning segment of Harvard's general education curriculum. Still, practicing ethical reasoning in the domain of human rights discourse presupposes some familiarity with the history and politics of the human rights movement. So prior to and alongside the philosophizing about human rights, this course introduces some background to that movement. Section 2, then, introduces some of the history and the political reality of human rights. Section 3 
discusses the UDHR itself. Section 4, 5, and 6 address the central question of why individuals would have human rights in the first place. By way of concluding, I make a few remarks on the universalism/relativism debate. I cannot address all topics of this course here, but this discussion should offer an introduction to its major themes.

2. Most cultures whose intellectual endeavors reached a certain degree of complexity have developed ideas of universal morality. There were also earlier declarations of rights, including the American Declaration of Independence of 1776 and the French Declaration on the Rights of Man and the Citizen of 1789. Alas, until the late $18^{\text {th }}$ century, at the earliest, logistic possibilities for any kind of international movement were lacking. And until the $20^{\text {th }}$ century there were no institutions with realistic global aspirations through which such morality could be implemented. Connected to those two points, until the $20^{\text {th }}$ century individuals had no standing in international law, which was entirely a matter of arrangements among states. Documents such as the 1648 Treaty of Westphalia mutually guaranteed protection to minorities, but it was a long way from there to giving individuals standing in international law. A world order based on national sovereignty had only limited use for the idea that individuals deserved to be protected especially from their governments. These attitudes only changed in the $20^{\text {th }}$ century. The "human rights movement" - the set of international and domestic (governmental and non-governmental) organizations and documents devoted to the realization of rights individuals have in virtue of being human - is in many ways a new phenomenon of the $20^{\text {th }}$ century. (For the history of the human rights movement, see Lauren (2003) and Morsink (1999).)

The human rights movement arose from a range of campaigns concerned with more specific issues. The first large-scale humanitarian effort of international proportions was the anti-slavery movement that began in the late $18^{\text {th }}$ century and saw its first major victory with the passing of the British Slavery Abolition Act in 1833. The labor movement of the $19^{\text {th }}$ century - which responded to the dismal living conditions of the working class following the Industrial Revolution -- also counts as predecessor to the human rights movement. The International Committee of the Red Cross too should be mentioned. That organization was founded by Henry Dunant after his devastating experience at the Battle of Solferino in 1859. Dunant was shocked by the terrible 
aftermath of the battle (which left 40,000 on the battlefield), especially the near-total lack of medical attendance. Thus inspired, he founded an institution (with standing under international law) charged with protecting life and dignity of victims of armed conflicts. Finally, I should mention the Women's emancipation movement. In 1879 the performance of Ibsen's play A Doll's House caused an international scandal by questioning the $19^{\text {th }}$ century understanding of marriage. The heroine, Nora Helmer, famously exclaims: "I believe that before anything else I'm a human being - just as much as you are.” This quote illustrates why the women's emancipation movement should indeed be considered a predecessor to the human rights movement.

At the 1919 Paris Peace Conference yet another issue surfaced that would become central to the human rights movement: equality among races. But while "selfdetermination of peoples" became an important goal of the conference, racial equality was side-lined. Among the results of the conference was that the League of Nation was founded (the predecessor to the UN); that peace became an international priority (and that the connection between peace and justice was acknowledged); and that the International Labor Organization (ILO) was founded to address the concerns of the labor movement. Alas, alongside the reluctance to acknowledge racial equality came a reluctance to question the colonial system that defined world politics. And as the economist John Maynard Keynes (a British delegate) illustrated in The Economic Consequences of the Peace, often moral language was used in a pointless way to accommodate Woodrow Wilson, the American president, whose opposition played a major role in excluding racial equality from further consideration.

An important step towards the UDHR was the Atlantic Charter of August 1941. Following a meeting between Churchill and Roosevelt on a ship on the Atlantic, the Charter stated goals for a peaceful world: self-determination, self-government, improved labor standards, economic advancement, social security, and "freedom from want and fear. The Charter became a rallying point for those who fought in the Second World War against Nazi Germany and its allies, and it was followed, on January 1, 1942, by the Declaration of the United Nations. The Charter of the United Nations (adopted in 1945) gave a prominent role to human rights, alas without explicating it in detail. That function fell to a separate declaration. The Charter included commitments to three ideas: self- 
determination of peoples; territorial integrity of states; and human rights of individuals. Any two of them can stand, and frequently have stood, in conflict.

Charged with drafting a declaration on human rights acceptable to members of the United Nations of rather diverse cultural backgrounds, the Commission on Human Rights started deliberating in January 1947. Since for the first time ever, individuals were given an explicit standing in international politics, with a prospect of also generating a legally binding status, this project triggered plenty of debate, reactions, and correspondence. The work of the commissions was a long-winded process of wrestling with formulations designed to be widely acceptable. This involved political struggles as well as philosophical debate (including an opinion poll of leading thinkers across the world). The commission was remarkably diverse by the standards of the time. It was chaired by Eleanor Roosevelt, who was not only Franklin D. Roosevelt's widow but a formidable public persona in her own right, and also included Charles Malik, the Chinese playwright, philosopher and diplomat Peng-Chun Chang, the Canadian legal scholar John Humphrey, the French judge René Cassin, the Indian educational reformer Hansa Mehta, and others from around the world. (Keep in mind, though, that when the UN was founded, it only had slightly more than 50 members because large parts of the world were still colonized then. Nowadays, there are more than 190 states.) The UDHR took the legal form of a declaration and was not binding at the time. (Nowadays there is some debate about whether parts of the UDHR have become binding through becoming customary law.) Work then began to formulate treaties to give human rights a binding shape, which eventually (with much delay) led to the International Covenants on Civil and Political Rights, and on Economic, Social, and Cultural Rights. Both were adopted by the UN in 1966, and went into effect in 1976. The Second World War had created a momentum that was difficult to maintain during the Cold War.

Even as news about extermination camps became confirmed, the Holocaust had little impact on the immediate war aims of the Allied. However, the Nazis atrocities were much present during the Commission's deliberations. One human rights document is older than the UDHR: the Convention on the Prevention and Punishment of Genocide. Its passing - on December 9, 1948 -- was the outcome of remarkable efforts by one man, Raphael Lemkin, a Polish-Jewish lawyer who had studied genocide before the Second 
World War and then barely escaped one himself. Not only did he spend years advocating for a convention concerned with this crime, but he also invented the term "genocide." There had previously been no word for that crime.

3. The UDHR reflects many of the evils humankind has experienced in history, not merely the Second World War and the Holocaust, but also, for instance, those troubles that had exercised the predecessor movements we encountered above. The document also reflects a concern with having an international Bill of Rights that would be broadly acceptable, as we already noticed when looking at Malik's speech. The preamble talks about "inherent dignity" and "worth" of human beings as well as of "equal and inalienable rights," but that is as far as its philosophical or religious commitments go. The preamble also reiterates the link between justice and peace that had been acknowledged in 1919 but only been insufficiently implemented. The preamble ends by referring to the list of human rights as a "common standard of achievement for all peoples and all nations," and makes clear that responsibility for their realization lies with "every individual and every organ of society." Mentioned is especially a charge to promote respect to human rights "by teaching and education."

Whereas a concern with non-discrimination was brushed aside in 1919, the insistence in Article 1 on all human beings being "born free and equal in dignity and rights" is immediately interpreted, in Article 2, in the sense that "[e]veryone is entitled to all the rights and freedoms set forth in this Declaration, without distinction of any kind, such as race, color, sex, language, religion, political or other opinion, national or social origin, property, birth or other status.” It is only after non-discrimination has been introduced that Article 3 declares that "[e]veryone has the right to life, liberty and security of person.” Article 4 revisits the concerns of the original humanitarian movement, the antislavery campaign, insisting that "[n]o one shall be held in slavery or servitude." Article 5 adds that "[n]o one shall be subjected to torture." To ensure that not much hangs on what counts as torture, this prohibition is also extended to "cruel, inhuman or degrading treatment or punishment." The UDHR does not explicitly prohibit the death penalty, nor does the International Convention on Civil and Political Rights. This contradicts the commitment of organizations such as Amnesty International, which regard the death 
penalty as "cruel, inhuman or degrading." It is only the second optional protocol to that Convention (of 1989) that prohibits executions.

Articles 6-12 are devoted to judicial matters, insisting on everybody's right to recognition as a person before the law; equality before the law; availability of remedies of rights violations; prohibition of arbitrary arrests; equal access to a fair and public hearing; a presumption of innocence; and protection against arbitrary interference with privacy. All of these matters had been ignored by Nazi judges. Article 13 guarantees freedom of movement within one's country as well as the right to leave any country and to return to one's country, but no right to enter other countries. Article 14, however, guarantees a right to asylum from prosecution. The presence of this article reflects a wide-spread unwillingness to help those prosecuted during the Holocaust. Article 13 is often referred to by Palestinians insisting on their right to return to the areas they left during the animosities between Israel and several Arab countries in 1947/8. Article 15 states that “[e]veryone has the right to a nationality," whereas Article 16 assures the "right to marry and found a family.” This too was a right the Nazis had trampled, restricting marriage on racial grounds. Article 17 guarantees a right to own property, which, alongside the right to asylum, was omitted in the subsequent covenants.

Article 18 guarantees the "right to freedom of thought, conscience, and religion," Article 19 the "right to freedom of opinion and expression;" and Article 20 the "right to freedom of peaceful assembly and association." Article 21 provides for a right to "take part in the government" of one's country, "directly or through freely chosen representatives.” The UDHR does not state a right to democracy. Whether there is such a right has been the subject of some debate. Article 21 does, however, talk about the will of the people as the basis of governmental authority, which "shall be expressed in periodic and genuine elections which shall be by universal and equal suffrage and shall be held by secret vote or by equivalent free voting procedures.”

The following articles address social and economic rights. Article 22 states a "right to social security" and does so in the context of mentioning "national effort and international co-operation.” Articles 23 and 24 have attracted criticism for stating rights many think are not of the sort of urgency to be human rights, or which should not be considered rights because it is not always practically up to states to realize them. Article 
23 guarantees a "right to work, to free choice of employment, to just and favorable conditions of work and to protection against unemployment," as well as a number of other labor rights. In addition, Article 24 recognizes the need to recuperation from labor, stating a "right to rest and leisure, including reasonable limitation of working hours and periodic holidays with pay.” These rights are the legacy of the labor movement. One of the most comprehensive articles, Article 25 declares a "right to a standard of living adequate for the health and well-being of himself and of his family, including food, clothing, housing and medical care and necessary social services, and the right to security in the event of unemployment, sickness, disability, widowhood, old age or other lack of livelihood in circumstances beyond his control." Article 26 provides for a right to education as well as a right of parents "to choose the kind of education that shall be given to their children" (as opposed to being ideologically prescribed by the state, as, say, in the Hitler Youth.)

The UDHR also contains cultural and community rights. Article 27 states a right "freely to participate in the cultural life of the community, to enjoy the arts and to share in scientific advancement and its benefits." Article 28 even states an entitlement to "a social and international order in which the rights and freedoms set forth in this Declaration can be fully realized." Only Article 29 mentions duties, namely, "duties to the community in which alone the free and full development of his personality is possible." Article 30, finally, insists that "nothing in this Declaration may be interpreted as implying for any State, group or person any right to engage in any activity or to perform any act aimed at the destruction of any of the rights and freedoms set forth herein.”

4. But why would people have such rights? This is a question for a philosophical investigation of human rights. Philosophy, as I have heard it put very aptly, is inquiry "in slow motion.” Philosophy asks more fundamental questions than we normally do in dayto-day reflection. The primary question in a philosophical investigation of human rights indeed is why human beings would have such rights in the first place, that is, why they would be standing in the kind of relationship where they can make such demands upon each other. This question concerns us for the remainder of this essay. We discuss three 
different responses. But let us begin with the question of what it means for people "to have a right.” We are interested in moral rather than legal rights. What it means to have a right is determined through the entitlements a legal system generates. But what does it mean to have a moral right? We are not yet asking why people would have moral rights, but simply what it means to have them.

This question is surprisingly difficult. On one view, to have a right means to have an interest whose protection is important enough to require a certain behavior of others, and to put the rights-holder in a position to demand such behavior. This is the "interest theory” of rights. This view is intuitive to such a degree that one may wonder whether it says anything non-trivial. But on second thought it is not trivial. If this is what it means to have rights, it would be peculiar to say God has a right to $\mathrm{X}$, since it would be peculiar to say that God's having a right would depend on His having an interest. Perhaps we do not want to say that God has rights, but it would be odd for this to be excluded on conceptual grounds. Rights of office-holders would also become elusive. Judges have rights ex officio, but their exercise is not necessarily connected to an interest.

Partly in response to such concerns others have proposed a different view of what it means to have a right, the "will theory." According to that view, to have a right means to have the ability to control whether others must act in particular ways. This theory makes sense of rights of God and of office-holders. But this account too has problems. There could now be no inalienable rights. One cannot surrender such rights. But there could be no such rights on this view because one way of controlling behavior of others in a certain domain is to get them to ignore one's wishes with regard to that domain. Moreover, on this account, nobody could have rights who cannot exercise control (animals, infants, the comatose). Some hybrid theory between these approaches is most likely to be correct, one according to which rights may be either interests or exercises of choice. We need not pursue this matter further, but it is worth nothing that even this seemingly straightforward matter raises tricky issues. (For more on these topics, see Edmundson (2004).)

So why would people have human rights? Why do people stand in the kind of relationship with each other that renders rights talk applicable? One traditional answer is - "by nature." Natural rights are rights that are not contingent upon the laws, customs or 
beliefs of particular societies. For this approach to answer our question of why people would have moral rights, we have to explicate just what this amounts to. The American Declaration of Independence offers one way of thinking about this matter: "We hold these truths to be self-evident, that all men are created equal, that they are endowed by their Creator with certain unalienable Rights, that among these are Life, Liberty and the pursuit of Happiness.” Saying something is self-evident means no further justification is possible or needed. But the thesis that there are equal rights for all is easy to doubt. Historically, many sophisticated people have taken for granted that people have differential rights, and that some have none, and they often had something to say in defense. So it is not self-evident that all humans have human rights. Self-evidence is not a good guide to truth. Self-evident to us merely is what we have gotten used to. This approach to natural rights is not helpful.

A common way of making sense of natural rights is through theology. Being "natural" means something like "being part of the divine creation." This approach permeates the thinking of one of the major thinkers in this tradition, John Locke (16321704). Locke's Second Treatise of Government is among the most important writings in the canon of Western political thought. "To understand political power right, and derive it from its original," says Locke, we must consider, what state all men are naturally in" (section 4). Locke envisages a "state of nature," a scenario without political arrangements. Rights are "natural" as opposed to conventional if people have them in this state. Why would people have rights in this state of nature, and how would we know?

Locke characterizes the state of nature as follows:

A state also of equality, wherein all the power and jurisdiction is reciprocal, no one having more than another; there being nothing more evident, than that creatures of the same species and rank, promiscuously born to all the same advantages of nature, and the use of the same faculties, should also be equal one amongst another without subordination or subjection, unless the lord and master of them all should, by any manifest declaration of his will, set one above another, and confer on him, by an evident and clear appointment, an undoubted right to dominion and sovereignty. (Section 4)

God did not create us in such a way that one group is superior, so Locke says. But why think this? After all, one may say (and people have often insisted) that "if God did not want one group superior to another, why did he create them differently?" 
A little later, Locke points out that the "state of nature has a law of nature to govern it, which obliges every one: and reason, which is that law, teaches all mankind, who will but consult it, that being all equal and independent, no one ought to harm another in his life, health, liberty, or possessions” (section 6). We also learn that with regard to life, health, liberty, and possessions persons have both duties and rights (section 7). Where possible without harming themselves, individuals must help others in preserving their life, liberty, health, limb, or goods.

But why do "equality" and "independence" lead to rights and duties, and why are we equal in relevant ways? We could continue to read this text, but will not find explicit answers. Locke tells us that we are the "workmanship" (section 6) of God, but that is consistent with there being a hierarchy among human beings. The best way of making sense of Locke's text is to hold that the reason why we are created equals is not just that we are all God's creatures, but that we are all created in the image of God. Qua human beings we have enough of a likeness to God that a basic moral equality among us is generated. This does not mean people are equal in every way, or even in every morally important ways. But enough equality is created thereby. Alas, if God is the source of rights, our theory of natural rights would intellectually be only as secure as our theology.

Others have tried to derive natural rights from human nature, famously Jacques Maritain (1882-1973), a French-Catholic theologian who was nevertheless committed to natural law that does not presuppose God. Maritain writes:

I am taking it for granted that you admit that there is a human nature, and that this human nature is the same in all men. (...) [M]an is a being gifted with intelligence, and who, as such, acts with an understanding of what he is doing, and therefore with the power to determine for himself the ends which he pursues. On the other hand, possessed of a nature, being constituted in a given, determinate fashion, man obviously possesses ends which correspond to his natural constitution and which are the same for all - as all pianos, for instance, whatever their particular type and in whatever spot they may be, have as their end the production of certain tuned sounds. If they don't produce these sounds they must be tuned, or discarded as worthless. But since man is endowed with intelligence, and determines his own ends, it is up to him to put himself in tune with the ends necessarily demanded by his nature. This means that there is, by virtue of human nature, an order or a disposition which human reason can discover and according to which the human will must act in order to 
attune itself to the necessary ends of the human being. The unwritten law, or natural law, is nothing more than that. (Maritain (1973), pp 34f)

But we must wonder, once we have set aside theology: Do human beings really have a function in the same way in which pianos do, and a corresponding excellence? More importantly, even if there were such an excellence, why must we act in accordance with it? It is hard to accept such reasoning once we have removed God from the picture. What Maritain says we might just as well deny, and then wonder how to make progress on the matter. In response to such difficulties, some have argued that - for better or worse! -- the idea of human rights, or the idea of equality, is untenable without theology. In any event, we cannot use theology to provide a philosophical account of human rights. We need to solve a problem of parochialism for such rights. That is, we must find some way of arguing that people have them that does not turn on philosophical and theological presuppositions that people cannot be reasonably expected to share (because, say, they turn on assumptions that people may reject without making a mistake they could in principle be made to see). Theology does not meet this test. Yet moving to a natural rights approach of the sort Maritain proposed - deriving rights from views about human excellence - is even less promising for this task.

5. Let us turn to a different approach, due to the German philosopher Immanuel Kant (1724-1804). Natural rights theorists of the sort we just encountered tried to locate rights "out in the world," in the sense that they were entailed by human nature, or else in the sense that God endowed human beings with rights in much the same way in which $\mathrm{He}$ endowed trees with leaves. As opposed to that, Kant derives morality, including rights, from the sheer fact that we are beings endowed with reason. A being endowed with reason falls into a contradiction in his mind when failing to abide by certain principles of morality. Kant is also the philosopher who has done most to theorize the notion of dignity that we also find on the UDHR.

The work of Kant's most commonly read in introductory classes is the Groundwork for the Metaphysics of Morals. Being an agent with reason means to see one's 
inclinations as possible grounds for action and then to decide whether to adopt them as guidelines for action, that is, as principles or maxims. Being such an agent means to have the capacity to act "on the representation of laws" (Groundwork, 4:412). It is the will that decides which inclinations to endorse by making them such maxims. Being an agent is not just feeling motivated by a sequence of desires the strongest of which becomes action-guiding. Instead, it means to let the will make a decision on that matter. The will is not entirely free in making decisions. Some principles constrain the will of a being with reason, principles Kant calls "objective," or "imperatives." Imperative may be "hypothetical" or "categorical." Hypothetical imperatives presuppose an end and recommend an action in its pursuit: "You need to do X if you want Y." The will is constrained because $\mathrm{X}$ does need to be done if the will wants $\mathrm{Y}$. By way of contrast, categorical imperatives constrain the will not relative to any end, but unconditionally. Categorical imperatives are guidelines of action whose worth we recognize by reason alone, and recognize as greater than the worth of any object of inclination. As Kant argues, there is only one Categorical Imperative, which he calls the "practical law," the "imperative of morality," or the "supreme moral principle." The Categorical Imperative is what morality is "all about." Kant offers various equivalent formulations of the Categorical Imperative. One of them is: "Act so that you use humanity in your person, as well as in the person of every other, always at the same time as an end, never merely as a means" (Groundwork, 4: 429). How does Kant derive this? Why does this principle constrain any act of willing, simply in virtue of its being an act of willing?

Generations of scholars have built their professional lives around throwing light on Kant's work. It would a striking success of philosophical reasoning to derive foundations of morality in this way. Roughly, here is what Kant does. Being a will with reason means setting ends or goals. The will chooses to do certain things rather than others. By setting ends, the rational will thinks of those ends as having value. For the will to adopt an inclination as a principle, it must endorse the end. In that sense, the rational will thus thinks of itself as conferring value. But we have reason to regard ends we set for ourselves as good, as having value, only to the extent that we esteem our capacity to set ends as something good. By assuming anything matters to us as an end, we must assume 
we matter ourselves, and do so in virtue of our being able to set ends. But every other being with reason also represents his existence in this way on the same grounds that also hold for any given person. That is, Kant says that if an agent views herself as having a value-conferring status in virtue of her power of rational choice - as she must - she must also understand that anyone with that power must have this same view of herself.

Why would this reasoning take us the Categorical Imperative? Suppose I am treating somebody merely as a means. Note that the Categorical Imperative does not say that one ought to treat others never as means. I am treating somebody as a means when I buy a subway ticket from her. Crucial is not to treat somebody merely as a means, as I would if the person from whom I just bought that ticket collapsed and I did nothing to help. So let us indeed suppose that I am treating somebody merely as a means. Then I am so treating somebody who must see himself as a source of value. However, the capacity in virtue of which he must do so is the same capacity I have myself. Disregarding that capacity means disregarding a capacity I must value. So, indeed, each rational nature must be taken seriously as end in itself, as a source of value. That is why, according to Kant, we can derive the supreme moral principle in this way. Examples Kant gives to illustrate the Categorical Imperative include duties not to commit suicide, not to lie, not to let one's talents rust, to refrain from excessive pride, and not to engage in mockery or gossip. Ruled out are also drunkenness, snobbery, servility and excessive humility.

"Dignity," according to Kant, characterizes the kind of worth rational beings have in virtue of the following properties: They set goals, and thus choose principles of action. This choosing, as an act of a rational being, is subject to the Categorical Imperative. Thereby, rational beings are the source of all other value. Dignity is an absolute worth grounded in the rational capacities for morality, and not conditional on how well these capacities are exercised. Dignity is not diminished through vice or bad action, nor is it increased through virtue or morally correct action. Wrongdoing may call for punishment (including death) and may be grounds for forfeiting certain rights, but not for regarding wrongdoer as worthless. Respect based on dignity is not something anybody has to earn. In the Anglo-American context, talk about respect is more common than talk about dignity. Dignity, however, in addition to appearing on the UDHR, features prominently 
for instance in the German legal tradition. The German Basic Law begins with a reference to dignity in Article 1, paragraph 1: "Human dignity shall be inviolable. To respect and protect it shall be the duty of all state authority.” Dignity appears before the right to life, which is a striking expression of the Kantian legacy. Life imprisonment without parole is unconstitutional because it violates dignity. Recently, a law to shoot down planes used as weapons was declared unconstitutional on grounds of dignity. The first law legalizing abortion in 1975 was unconstitutional because the Constitutional Court held that embryos had dignity. (Early-term abortions continue to be illegal, but the state declines to prosecute.) Peep shows were once ruled to violate the performers' dignity, regardless of their own attitudes. Following Kant, one cannot relinquish one's dignity. Shows where performers cannot see the viewers remain outlawed.

Let us apply Kant's ideas about dignity to the question of the acceptability of torture. Article 5 of the UDHR states that " $[\mathrm{n}] \mathrm{o}$ one shall be subjected to torture or to cruel, inhuman or degrading treatment or punishment.” Nevertheless, the debate about torture continues. At its heart we find references to "ticking-bomb cases." Suppose we know for sure that X planted a bomb somewhere that is about to explode and would kill many. X confesses but refuses to reveal the location of the bomb. Suppose there are no other ways of extracting this information. Surely, the argument concludes, we should be allowed to apply torture. (For this argument, see Shue (1978).) One cannot simply respond that “torture does not work anyway.” Whether torture “works” depends on the circumstances. If the question is "Did Saddam Hussein collaborate with bin Laden?,” confessions under torture might well be useless. Yet if statements are readily verifiable, it is peculiar to exclude torture because it does not work. Another bad response is to say that using torture is unwise because it will only make the angry even angrier. That response might leave us with cases of torture that could be carried out secretively.

Better responses are these two. First, the assumptions of the argument are strong. Rarely do we know for sure that a person is guilty as charged. Rarely is torture the only remaining possibility for ascertaining the information. Other tactics include incentivized cooperation; the good cop/bad cop strategy; the pushing of emotional buttons (say, to make perpetrators see victims as persons, or to think about the pain they would inflict on 
their own families); and a pumping-up of the ego ("unlike those people, you are not the kind of person who would do such things”). A second point is that if torture were permitted, there would have to be torturers, and they would have to receive instruction and supervision. Torture would have to be institutionalized. It is unrealistic that this could be done without torture being applied more widely than intended. To put the point bluntly, in a manner ascribed to Mark Twain: “To a man with a hammer, everything looks like a nail.” An exacerbating factor is that people often have limited capacities to relate to another's pain, to understand "what torture is like."

So the ticking-bomb argument can be resisted, to the extent that the possibility of such extreme scenarios is supposed to have any implications for the regulation of torture. However, we need to resort to other considerations to articulate the idea that "there are certain things we must never do to people.” The notion of dignity does this work. Consider the following account of what is troublesome about torture:

[T]he torture victim finds herself to be not only physically and morally defenseless, but exposed to a will that appears largely if not completely arbitrary. The victim's greatest interests are completely subject to the caprice of her torturers (....) Insofar as she is able to form any estimates of their motives and intentions, the victim must trust in the sincerity of people who have already shown that they have no scruples about how they treat her. (Sussman (2005), pp 7f) [T] orture fails to respect the dignity of its victim as a rationally self-governing agent. (...)[T]orture (...) involves a deliberate perversion of that very value, turning our dignity against itself (...) It is perhaps not accidental that many of the most common forms of torture involve somehow pitting the victim against himself, making him an active participant in his own abuse. In Abu Ghraib, captives were made to masturbate in front of jeering captors. Here the captive was forced into the position of having to put his most intimate desires, memories, and fantasies into the service of his torturers, in a desperate attempt to arouse himself for their amusement. The US soldiers could beat and killer their prisoners, but only the prisoner himself could offer up his own erotic life to be used against himself in this way” (Sussman (2005), pp 19-22).

This account of the wrongness of torture proceeds differently from the two considerations against the ticking-bomb argument I offered above. It makes the notion of dignity central to what could be extended into an argument against any application of torture, as stated by Article 5 of the UDHR. 
6. Recall our guiding question: what would the nature of the relationship among human beings have to be like for us to claim moral rights against each other? Kant offers one rather prominent response to this question, one based on consistency of reason. We have certain rights because beings with reason cannot consistently treat others in ways that do not grant them rights. The centrality of reason to this account also allows for an articulation of a notion of dignity that has become so important to the human rights movement.

Alas, there are problems with the derivation of the Categorical Imperative. The derivation aims to pinpoint a contradiction that arises if I am treating somebody merely as a means. Yet no contradiction arises if $I$ am using you as a means to ends that have value because I have conferred it upon them. That I value certain things only permits the inference that I must value my having the capacity to value, or my partaking of humanity. By the same reasoning, you must value your having the capacity to value, or your partaking of humanity. I must value the capacity to value, or to set ends, insofar as it is a capacity that I possess. You must value that capacity insofar as it is a capacity you possess. I do not need to value your capacity to value, and vice versa. Neither you nor I must value the capacity to value per se. No contradiction arises if $I$ am using you as a means to ends that have value because $I$ have conferred it upon them. What the argument demonstrates is how you become intelligible to me as an agent, how I come to see your actions as more than mere events -- by coming to realize that, in a fundamental way, we are alike. It might imply more, but not that I am inconsistent when not treating you as an end. A Kantian might object that we are now drawing an arbitrary distinction between your capacity to value and mine. But if it is arbitrary to do so, that move will be unreasonable, but not introduce an inconsistency. The goal of the Kantian enterprise has been to offer an inconsistency argument, and that goal seems out of reach.

Kantians sets the standards high. If indeed rights can be established only by showing that their violation leads to a contradiction in the mind, perhaps we are asking too much. What we should seek to establish is the unreasonableness of treating people merely as means or even of treating them as moral unequals, rather than the inconsistency that lies in doing so. Consider the following statement by the philosopher Joel Feinberg: 
The real point of the maxim that all men are equal may be simply that all men equally have a point of view of their own, a unique angle from which they view the world. They are all equally centers of experience, foci of subjectivity. This implies that they are all capable of being viewed by others imaginatively from their own point of view. They 'have shoes' into which we can always try to put ourselves; this is not true of mere things. It may follow (causally, not logically) from this way of so regarding them that we come to respect them in the sense tied to the idea of 'human worth.' (...) In attributing human worth to everyone we may be ascribing no property or set of qualities, but rather expressing an attitude - the attitude of respect - towards the humanity in each man's person. That attitude follows naturally from regarding everyone from the 'human point of view', but it is not grounded on anything more ultimate than itself, and it is not demonstrably justifiable. (Feinberg (1973), pp 93f)

In the spirit of this statement, we should seek to show that it would be unreasonable to disregard human rights, rather than inconsistent (and to do so without getting into the problems we encountered in section 4 with those natural-rights approaches to human rights). This move would give up on a major ambition of moral thought, to offer an actual derivation, an unassailable demonstration of morality. But we have found some indication that this is asking too much.

A number of philosophers have recently made attempts to provide accounts of human rights along the lines just sketched. One of them is James Griffin's 2008 book On Human Rights. Griffin views human rights as protections of "normative agency," agency involved in choosing a worthwhile life. According to Griffin, "what we attach value to, what we regard as giving dignity to human life, is our capacity to choose and to pursue our conception of a worthwhile life" ( $p$ 44), and "it is the mere possession of this common capacity to identify the good that guarantees persons the protection of human rights.” (p 46) Throughout, Griffin argues for the enormous normative significance of certain aspects of our shared humanity by way of comparison to other goods, and insists on the unreasonableness of disregarding these aspects -- without, however, insisting that somebody who fails to do so falls into a contraction with himself.

Central is the idea of a distinctively human life. "Human life," explains Griffin, is different from the life of other animals. We human beings have a conception of ourselves and of our past and future. We reflect and assess. We form pictures of what a good life would be - often, it is true, only on a small scale, but occasionally also on a large scale. And we try to realize these pictures. This is what we mean by a distinctively human existence - distinctive so far as we know. (...) And we value our status as human beings especially highly, even more highly than even our happiness. 
This status centers on our being agents - deliberating, assessing, choosing, and acting to make what we see as a good life for ourselves. (p 32)

To be an agent, in the fullest sense, one must choose one's path through life (that is, not be dominated or controlled by someone else); one's choice must be real (that is, one must have at least a minimum of education and information, be able to act, and have at least a minimum of resources and capabilities); and others must also not forcibly stop one from pursuing what one sees as a worthwhile life. Therefore what human rights ought to protect is a certain amount of autonomy, liberty, and the availability of at least minimal provisions. At this level, Griffin thinks, the approach holds universally and applies across societies. This does not mean that "human rights" have independently arisen in different cultures. Nevertheless, human rights developed in reaction to abuses, especially religious intolerance, government oppression, and discrimination. These abuses occur everywhere, and the substantive values human rights protect are appreciated everywhere.

What is protected, following this reasoning, is a right to life and security of the person (otherwise personhood is impossible); a voice in political decision (a key exercise of autonomy); free expression, assembly, and press (for the exercise of autonomy not to be hollow); the right to worship (a key exercise of what many take to be point of life); the right to basic education and minimum provisions needed to be functioning as a person (which is more than what is needed for mere physical survival); the right not to be tortured (since, among its several evils, torture destroys one's capacity to decide and to stick to the decision). What would be hard to obtain, as far as the rights on the UDHR are concerned, are a right to freedom of residence (included in Article 13), a right to protection against attacks on one's honor and reputation (included in Article 12), a right to equal pay for equal work (in Article 23), and a right to holidays with pay (Article 24).

Recall that for Kant, dignity is inviolable. Applied to torture, this means torture is arguably never justified. According to Griffin, dignity is not categorically inviolable, though the standards for violations are high. If we apply this reasoning to torture, we find that it is not categorically impossible to justify torture in particular cases (such as tickingbomb cases), though plausibly this reasoning would nevertheless support a general prohibition of torture, based on the considerations that plausible ticking-bomb cases will be rare, and that regulation of torture entails its own problems. Empirical information 
about human nature and human societies, as well as about the limits of human understanding and motivation, enters into Griffin's account and is needed to determine the contents of human rights. "Practicalities," as Griffin says, help determine how much is expected, and who is expected to do it. As an example, consider the right to life. This right implies a claim to health support necessary for maintaining human status, but not that life be extended as long as possible, given the enormous costs of end-of-life care.

7. An account like Griffin's, by and large, strikes me as the most sensible way of grounding human rights, understood as rights we have "simply in virtue of being human." I say an account "like” Griffin's because other philosophers have offered accounts of human rights not built on the idea of normative agency, but on ideas such as basic human needs or capabilities. But for each of these accounts it is true that it does not make good on the ambitions of natural rights thinkers who located the basis for such rights "in the world," nor does it make good on the Kantian ambition to base rights on the consistency of reason alone. Instead, it develops ideas about the normative significance of the distinctively human life and the unreasonableness of acting in ways that threaten such life. That much is all we can do to secure human rights intellectually, but that much is also all we need to do to that end.

I conclude with a few remarks on moral relativism. Moral relativism is the thesis that fundamental values and ethical beliefs are culture-bound in a sense that does not allow for any critical engagement with people who do not belong to that culture, and makes it the case that there is no right and wrong, but merely a "right for" and "wrong for." The emphasis on "fundamental" differences is crucial. Often differences in moral codes are due to differences in living conditions rather than to fundamentally diverging commitments. As opposed to that, universalism of the sort that motivates the human rights movement holds that there are values that apply across cultures, even if the cultures themselves do not accept them. To the extent that the arguments for an approach like Griffin's succeeds, we ipso facto have a rebuttal of relativism, but let me nevertheless make a few additional remarks on this subject on account of its importance for the enterprise of grounding human rights. 
To begin with, we live in an interconnected world, and the question of what we ought to do for each other arises in numerous ways: we have to confront it. Human beings have irreversibly encountered each other. Second, persons across cultures share vulnerabilities: they suffer from physical pain, require food and water to survive, and are susceptible to disease ad malnutrition. People across cultures also aspire for common goods: bodily health; bodily integrity; and a desire to be treated with some respect in their affiliations. The idea of a distinctively human existence, if we understand it thinly, is not culturebound. Common vulnerabilities and goods make intercultural exchange intelligible. The human rights movement answers the question of how we ought to live together at the global level, by taking seriously common vulnerabilities and goods, by considering how, historically, these have been assaulted and ignored, and by then formulating a language specifically of rights in response.

Third, views that categorically restrict the scope of fundamental moral values to particular cultures or circles within cultures inevitably draw on reasoning that is hard to defend and force upon others. History abounds in failed attempts to do so. And finally, those who speak in support of relativism are often those in power, whereas those who reject it generally focus on the standpoint of the victims. To the extent that representatives of certain cultures reject human rights by saying something like "around here we do things differently," their argument often rests on an attribution of unanimity in their own culture that does not exist, and is especially implausible for egregious human rights violations. As Scanlon (2003) put it, we must then wonder: "[W]hich is the more objectionable form of cultural superiority, to refuse to aid a victim on the ground that 'they live like that - they don't recognize rights as we know them,' or to attempt to protect the defenseless even when they themselves feel that suffering is their lot and they have no basis to complain of it?” (P 119) In specific cases this actually is a genuinely open (and very difficult) question. But often enough, I think, the correct answer is the second one.

\section{Literature}


Edmundson, Williams. 2004. An Introduction to Rights. Cambridge: Cambridge University Press

Feinberg, Joel. 1973. Social Philosophy. Englewood Cliffs: Prentice Hall

Glendon, Marie Ann. 2001. A World Made New: Eleanor Roosevelt and the Universal Declaration of Human Rights. New York: Random House

Griffin, James. 2008. On Human Rights. Oxford: Oxford University Press

Hathaway, Oona. 2002. "Do Human Rights Treaties Make a Difference?," Yale Law Journal 111: pp 1935-2042

Kant, Immanuel. 2002. Groundwork for the Metaphysics of Morals. Ed. by Allen Wood. New Haven: Yale University Press

Lauren, Paul Gordon. 2003. The Evolution of International Human Rights. Philadelphia: University of Pennsylvania Press

Locke, John. 1988. Two Treatises of Government. Ed. by Peter Laslett. Cambridge: Cambridge University Press

Maritain, Jacques. 1971. The Rights of Man and Natural Law. New York: Gordian Press

Morsink, Johannes. 1999. The Universal Declaration of Human Rights. Philadelphia: University of Pennsylvania Press

Risse, Thomas, Stephen Ropp, and Kathryn Sikkink (eds.). 1999. The Power of Human Rights: International Norms and Domestic Change. Cambridge: Cambridge University Press

Scanlon, T. M. 2003. "Human Rights as a Neutral Concern, chapter 6 of Scanlon, The Difficulty of Tolerance. Cambridge: Cambridge University Press

Shue, Henry. 1978. “Torture,” Philosophy and Public Affairs 7: pp 124-143

Sussman, David. 2005. "What's Wrong with Torture?, Philosophy and Public Affairs 33: pp 1-33 